\title{
The effects of ownership structure and industry characteristics on export performance
}

\author{
Evidence from Chinese Manufacturing Firms
}

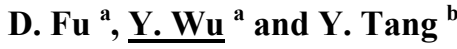 \\ ${ }^{a}$ Economics(M251), Business School, The University of Western Australia, Perth, Australia; ${ }^{b}$ School of \\ International Trade and Economics, Central University of Finance and Economics, Beijing, China \\ Email: yanrui.wu@uwa.edu.au
}

\begin{abstract}
China has achieved spectacular growth in exports in the past three decades and became the world's largest exporter of manufactured goods in 2009. Exploring the determinants of the export performance at the firm level is a critical step to understand the success of the Chinese exports. While the existing economic literature mainly focuses on the role of firm heterogeneity such as productivity, firm size, and innovation activities in determining export performance of firms, researchers from the international business field argue that the determinants of export performance should be assessed at the two broad levels, that is, the external environment level and the internal level.
\end{abstract}

In response to this claim, we adopt an integrative framework incorporating the governance-strategyperformance (GSP) paradigm and structure-conduct-performance (SCP) to examine the impact of ownership structure (internal factors) and industry characteristics (external factors) on the export performance of Chinese manufacturing firms. To achieve this aim, three different yet related models are employed, namely, the logit model, tobit model and ordered probit model, to investigate the effects of covariates of our interest on the export propensity, export intensity and export strategies of Chinese firms in the manufacturing sector during the period 1999-2003, respectively. Unlike the existing studies, this paper not only distinguishes domestic firms from foreign firms but also differentiates wholly-owned enterprises from joint ventures with different dominant equity holders. We also consider the effect of industry characteristics captured by industry concentration, industry export-orientation and industry capital intensity.

We find that the presence of wholly-owned firms and joint ventures with foreign control has a positive effect on export propensity and intensity. Firms with non-HMT control are more export-oriented than those with HMT control. Furthermore, firms with such characteristics are more likely to be persistent exporters, with the exception of joint ventures with HMT control, which are less likely to export persistently. Joint ventures with domestic control (non-state or state control) and wholly locally owned enterprises are less likely to export or improve their export status, and have lower export intensity. Moreover, the impact of industry concentration on export performance remains inconclusive, meaning further studies or the use alternative measurements are required. The findings about the effects of industry export orientation and capital intensity are consistent across the three different models. The results imply that firms operating in export-oriented and labour intensive industries are more likely to export, have high export intensities, and be persistent exporters.

Keywords: Export performance, Chinese firms, Ownership, Industry characteristics 


\section{INTRODUCTION}

Exports have been the primary engine of Chinese economic growth. Over the past three decades, China has enjoyed a phenomenal growth in exports at an annual rate of 18.6 percent. In recent years, falling international demand and rising labour costs have negatively affected Chinese exports growth, raising concerns among policy makers. Correspondingly, stimulus measures such as reducing a structural tax, raising export tax rebates, and providing financial support have been adopted to boost exports. However, these actions, which are targeted at specific industries and firms, are largely based on macroeconomic evidence that could create unreasonable expectations about the effects of export promotion policies. To reduce the risk that improper measures are taken, a firm-level analysis of export performance is thus necessary.

The past decade has witnessed the emerging discussion of export performance at the firm level in the economics and business literature which has asked this basic question: what are the determinants of firms' export performance? Though many studies have advanced our understanding of firms' export behaviour, there are still few studies that simultaneously investigate the effects of the internal and external factors on export performance (Zhao and Zou, 2002). In particular, two questions remain relatively unexplored. First, how do the interactions between foreign-invested firms and domestic investors within the context of corporate governance influence their international activities (Filatotchev et al., 2008). Second, how do industry characteristics affect the export performance of firms in large and open economies (Gao et al., 2010). This paper will contribute to answering these questions by examining the impact of ownership structure and industry characteristics on export performance using a panel data of 36,941 Chinese manufacturing firms for the period 1999-2003. This period corresponds to the pre- and post-WTO period in China.

In this study, ownership structure and industry characteristics are considered to be important factors affecting export performance. Three indicators (i.e. export propensity, export intensity and export strategy) are used to capture export performance. Correspondingly three different models, namely, logit, probit and ordered probit models are employed. Furthermore, unlike previous studies, this study will not only distinguish domestic firms from foreign firms but will also distinguish wholly-owned enterprises from joint ventures with different dominant holders. This analysis will also consider industry characteristics including industry concentration, industry export-orientation and industry capital intensity.

\section{DATA AND METHODS}

\subsection{The Dataset}

The dataset employed in this study is drawn from Annual Survey of Chinese Industrial Firms (ASCIF) from 1999 to 2003 by National Bureau of Statistics of China (NBSC). The database covers all firms with annual sales above 5 million yuan (RMB). After cleaning the missing or negative key variables, we have a balance panel of 36,941 firms in the five consecutive years.

\subsection{The Econometric Model}

To comprehensively examine the effects of ownership structure and industry characteristics on export performance, three different indicators of export performance (i.e. export propensity, export intensity and export strategy) are used as dependent variables. It is assumed that firms' ownership structure and industry characteristics could affect firms' export performance, together with other firm-specific covariates. The baseline specification can be presented as follows:

$$
Y_{i t}=a+b_{1} O_{i(t-1)}+I_{i j(t-1)}^{\prime} b_{2}+Z_{i(t-1)}^{\prime} b_{3}+X_{i t}^{\prime} b_{4}+e_{i t}
$$

where subscripts $i, j$ and $t$ denote firm, industry, and year; $Y$ is the dependent variable representing the export performance, which can be binary, fractional or ordinal in this paper; $o$ denotes ownership structure of firm $i$, and $I$ denotes a vector of industry characteristics variables that include industry concentration index, industry export-orientation index and industry capital intensity if firm $i$ operates in industry $j, Z$ denotes a vector of control variables that include firm productivity, size and age. Some other variables $(X)$, like region, industry and year dummies, are also included to control some unobserved macroeconomic shocks and fixed effects. Given the possible effects of exporting on firms' characteristics, we follow the traditional method in the literature and lag all the independent variables one year to alleviate the problem of simultaneity. The heteroskedasticity resulting from unobserved firm heterogeneity will also be considered. In particular, the fixed effects model cannot be used here because the ownership structure as an independent variable may be constant over time and could be swept away by the fixed effects transformation. Therefore, the random 
effects model is preferred by assuming that unobserved firm heterogeneity is uncorrelated with each explanatory variable in all time period.

\section{Dependent Variable}

To examine the determinants of export propensity in Chinese manufacturing firms, the dependent variable in equation (1) is represented by a binary variable $\left(E X P D_{i t}\right)$, which equals one when the firm has positive exports values $\left(E X P_{i t}^{*}\right)$ in a specific year and zero otherwise.

$$
\text { EXPDit }= \begin{cases}1 & \text { if EXP } P_{i t}^{*}>0 \\ 0 & \text { if otherwise }\end{cases}
$$

As shown in Table 1, over one third of the considered firms were involved in exporting activities. If the export performance is represented by the export intensity (i.e. $E X P T_{i t}$, the ratio of export value to total sales), the dependent variable will be a fractional variable with a large number of zero value. We calculate the export intensity using the following formula:

$$
\text { EXPT } T_{i t}=\frac{\text { Exports }_{i t}}{\text { Total Sales }}
$$

The average export intensity in the sample is about one fifth, meaning that about twenty percent of the output of Chinese firms was sold in foreign markets. Besides the export propensity and export intensity, an ordinal dependent variable is also considered in this paper. In turn, three groups of firms in terms of export strategy $\left(E X P S_{i}\right)$ are identified: non-exporters which are defined as firms who never exported in the investigated period; sporadic exporters, which were those that exported in some years of the period; and persistent exporters which were those that exported every year. The dependent variable in such occasion is defined as three categorical and ordinal numbers as follows:

$$
\text { EXPS } S_{i}=\left\{\begin{array}{l}
1 \text { if sum }\left(E X P D_{i}\right)=0 \\
2 \text { if sum }\left(E X P D_{i}\right) \in[1,4] \\
3 \text { if sum }\left(E X P D_{i}\right)=5
\end{array}\right.
$$

\section{Independent variables}

Based on the information from the dataset, there are two ways to identify the firm's ownership structure. The first method is to directly utilise the firms' registration ownership type, which falls into the following ownership categories: state-owned-enterprises, collectively-owned enterprises, overseas joint ventures, foreign joint ventures, and limited liability companies, sharing holding firms, Hong Kong, Macau and Taiwan enterprises (HMT), foreign invested enterprises and others. The second approach is to use the information on the sources of total registered capital (equity), which includes state capital, collective capital, private capital, HMT capital, foreign capital and capital from legal entity; to identify the firm's ownership structure indirectly. However, the outcome of these two methods does not exactly match. This study follows Ge and Chen (2008) and uses the sources of the registered capital to identify the ownership structure.

The firms' ownership structure is thus classified into eight categories: (1) wholly foreign-owned enterprises with non-HMT control; (2) wholly foreign-owned enterprises with HMT control; (3) joint ventures with nonHMT control; (4) joint ventures with HMT control; (5) joint ventures with non-state control; (6) joint ventures with state control; (7) wholly locally-owned enterprises with non-state control; (8) wholly locallyowned enterprises with state control. The "other type" of ownership structure will be a benchmark. A wholly foreign invested enterprise is an enterprise with all the registered equity from foreign investors, who are from Hong Kong, Macao and Taiwan (HMT) and other foreign countries (mainly OECD countries). A wholly locally-owned enterprise is one wholly-owned by local investors including state investors and nonstate investors. A joint venture is defined as a company with positive foreign capital and local capital. Non-state capital for these purposes includes collective capital, private capital and legal entities capital. A control structure means that the investor of that category enjoys a dominating capital share in a specific enterprise. Table 1 shows that more than half the firms were wholly invested by local investors with a non-state control structure and about 16.5 percent were controlled by state investors. The rest (about 30 percent) of the firms had foreign capital and 12 percent are totally owned by foreign investors.

Following the literature, we categorise industry characteristics of Chinese manufacturing industries using the following measures: (1) industry concentration, by calculating the Herfindahl index (HI), which is measured by the sum of the squares of the market shares of each firm competing in a specific industry; (2) industry export-orientation index (IEI), the percentage of exporters in a specific industry; (3) industry capital intensity 
(ICI) index measured by the ratio of total fixed assets to total employee in a specific industry. The higher value of HI implies a more concentrated industry while the higher IEI implies a more export-oriented industry. The lower ICI represents a labour-intensive industry. These three variables are all calculated at the four-digit industry level.

\section{Control variables}

Three control variables are included in this study. The total factor productivity (TFP) was calculated by employing the Levinsohn and Petrin approach (2003) at the two-digit level. In the economic literature, numerous studies have provided consistent evidence that firm productivity plays a positive role in firms' export behaviour (i.e. the self-selection hypothesis). We also controlled for firm Size, as measured by the number of employees and firm Age, as measured by the number of years since the establishment of the firm. Region, industry, and year effects are also incorporated in the estimate for robustness.

\section{RESULTS AND DISCUSSION}

\subsection{The Determinants of Export Propensity and Export Intensity}

Following previous studies, such as Gao et al. (2010) and Fung et al. (2008), we employ Logistic (LOGIT) and TOBIT models for the estimation of export propensity and export intensity, respectively. We present three specifications with different sets of independent variables (i.e. ownership structure variables, industry characteristics variables and combined variables) for export propensity and export intensity to clarify the proposed hypotheses. The results for the determinants of export propensity and for the export intensity are displayed in Tables 1 and 2, respectively. The Wald Chi-square statistics reveal that the null hypothesis that the regression coefficients are jointly equal to zero can be rejected at the one percent significance level for all regressions.

Foreign control structure has positive effects on export propensity and export intensity, regardless of the source of the foreign capital. In contrast, firms governed by local investors are less likely to enter foreign markets and more likely to show lower export intensity. In particular, firms wholly owned by foreign investors with non-HMT controls (mainly from the OECD countries) have the highest export propensity and export intensity, while wholly locally-owned enterprises with state controls are the least likely to export and have the lowest level of export intensity. As for the joint ventures, the dummy variables for JVs with HMT control or non-HMT control have positive coefficients, while JVs with non-state control or state control have negative coefficients. These results imply that the export propensity and export intensity of Chinese manufacturing firms is positively associated with not only the volume of foreign capital but

Table 1.Determinants of Export Propensity

\begin{tabular}{|c|c|c|c|}
\hline \multirow[b]{2}{*}{ Independent Variables } & \multicolumn{3}{|c|}{ Export Propensity (Logit Model) } \\
\hline & $\begin{array}{l}\text { Ownership } \\
\text { structure } \\
\text { Model } 1\end{array}$ & $\begin{array}{c}\text { Industry } \\
\text { Characteristics } \\
\text { Model } 2\end{array}$ & $\begin{array}{c}\text { Combined } \\
\text { Model } 3\end{array}$ \\
\hline Ownership Structure & & & \\
\hline $\begin{array}{l}\text { WFOEs with non-HMT } \\
\text { control }\end{array}$ & $2.388(0.00)$ & & $2.064(0.00)$ \\
\hline WFOEs with HMT control & $1.605(0.00)$ & & $1.297(0.00)$ \\
\hline JVs with non-HMT control & $1.337(0.00)$ & & $1.244(0.00)$ \\
\hline JVs with HMT control & $0.649(0.01)$ & & $0.514(0.03)$ \\
\hline JVs with nonstate control & $-0.375(0.11)$ & & $-0.447(0.05)$ \\
\hline JVs with state control & $-0.748(0.01)$ & & $-0.682(0.01)$ \\
\hline $\begin{array}{l}\text { WLOEs with nonstate } \\
\text { control }\end{array}$ & $-3.512(0.00)$ & & $-3.171(0.00)$ \\
\hline WLOEs with state control & $-3.817(0.00)$ & & $-3.387(0.00)$ \\
\hline Industry Characteristics & & & \\
\hline Industry concentration & & $0.199(0.64)$ & $0.624(0.12)$ \\
\hline Industry export orientation & & $8.651(0.00)$ & $7.604(0.00)$ \\
\hline Industry capital intensity & & $-0.002(0.00)$ & $-0.003(0.00)$ \\
\hline Control Variables & & & \\
\hline TFP $(\log )$ & $0.248(0.00)$ & $0.426(0.00)$ & $0.295(0.00)$ \\
\hline Firm size $(\log )$ & $1.589(0.00)$ & $1.562(0.00)$ & $1.471(0.00)$ \\
\hline Firm age (log) & $0.006(0.88)$ & $-0.343(0.00)$ & $0.041(0.25)$ \\
\hline Log likelihood & -39587 & -40046 & -38634 \\
\hline Wald $\chi^{2}$ & $14950.1(0.00)$ & $13259.1(0.00)$ & $13779.7(0.00)$ \\
\hline Number of observations & 147,764 & 147,764 & 147,764 \\
\hline
\end{tabular}

Note. All the independent variables are lagged one year. Province, two-digit industry, and year fixed effects are included and not shown. The p-values are reported in parentheses.

WFOEs=wholly foreign-owned enterprises; HMT=Hong Kong, Macao, and Taiwan; $\mathrm{JVs}=$ Joint Ventures; LOEs=wholly locally-owned enterprise also the extent of foreign investors' control over the decision-making within the enterprises. Hence both Hypotheses 1 and 2 are supported. It is also interesting to note that firms with non-HMT capital are more export-oriented and export-intensive than those with HMT capital, while firms involving state capitals are 
less export-oriented and export-intensive than those with non-state capital. These results indicate that Hypothesis 3 is also supported.

These findings are actually consistent with the changes in the modes of inward FDI into China in recent years. In the early stage of reform, contractual joint venture and joint exploration investment played a dominant role in the entry modes of FDI in China. These were later replaced by equity joint venture and wholly foreignowned enterprises after 1986. Since the 1990s the share of wholly foreign-invested enterprises has gradually increased, and the foreign control in joint ventures has also increased. From 1998 onwards, the share of wholly foreign-owned enterprises exceeded that of equity joint ventures. By 2000, the share of wholly foreign-owned enterprises and contractual joint ventures had accounted for 80 percent of both total contractual and actual investment. ${ }^{1}$ Meanwhile, the contribution of foreign-invested enterprises to China's exports also increased dramatically. The share of exports by FIEs in total exports had increased from 0.15 percent in 1981 to 58.30 percent in 2005. Even in the measurement period between 1999 and 2003, the record also increased from 45.47 percent to 54.84 percent. Recent related research by Feenstra and Hanson (2005) has also confirmed that multinational enterprises engaged in export processing in China are more likely to have the ownership of the factories.

The study also found that the estimated coefficient of Herfindahl index is positive but not statistically significant for export propensity, while the coefficient is negative but insignificant for export intensity. This implies that the impact of industry concentration on the export propensity and export intensity of Chinese firms is inconclusive. This is contrary to Zhao and Zou (2002), in which they found that industrial concentration has a negative influence on both export propensity and export intensity. On this basis, Hypothesis 4 can be rejected.

The coefficients of industry export orientation and capital intensity are statistically significant at one percent significance level, meaning firms operating in export-oriented and labour-intensive industries are more likely to export and have higher export intensity. This demonstrates that Chinese exporters are enjoying export spillovers and utilising the comparative advantage of the abundant cheap labour, thus supporting Hypotheses 5 and 6.

In relation to the effects of the control variables, the results show that firms with higher productivity are more likely to export and export more, which is evidence supporting the self-selection hypothesis in China. The firm size in terms of total employees also exerts a positive influence on firms' export propensity and export intensity. It could be argued that large firms usually own large amounts of equity, advanced technology,

intangible assets, or brand name; which could give them a competitive advantage in foreign markets that small firms do not have. Meanwhile, the effect of firm age on export decision is not particularly significant for the export decision of firms but has a negative influence on export intensity. This implies that Chinese exporters with long history
Table 2.Determinants of Export Intensity

\begin{tabular}{|c|c|c|c|}
\hline \multirow[b]{2}{*}{ Independent Variables } & \multicolumn{3}{|c|}{ Export Intensity (Tobit Model) } \\
\hline & $\begin{array}{c}\text { Ownership } \\
\text { structure } \\
\text { Model } 4\end{array}$ & $\begin{array}{c}\text { Industry } \\
\text { Characteristics } \\
\text { Model } 5\end{array}$ & $\begin{array}{l}\text { Combined } \\
\text { Model } 6\end{array}$ \\
\hline \multicolumn{4}{|l|}{ Ownership Structure } \\
\hline WFOEs with non-HMT control & $0.119(0.00)$ & & $0.123(0.00)$ \\
\hline WFOEs with HMT control & $0.091(0.00)$ & & $0.093(0.00)$ \\
\hline JVs with non-HMT control & $0.066(0.00)$ & & $0.071(0.00)$ \\
\hline JVs with HMT control & $0.049(0.00)$ & & $0.050(0.00)$ \\
\hline JVs with nonstate control & $-0.036(0.02)$ & & $-0.035(0.02)$ \\
\hline JVs with state control & $-0.078(0.00)$ & & $-0.074(0.00)$ \\
\hline WLOEs with nonstate control & $-0.217(0.00)$ & & $-0.212(0.00)$ \\
\hline WLOEs with state control & $-0.249(0.00)$ & & $-0.243(0.00)$ \\
\hline \multicolumn{4}{|l|}{ Industry Characteristics } \\
\hline Industry concentration & & $-0.033(0.21)$ & $-0.018(0.48)$ \\
\hline Industry export orientation & & $0.514(0.00)$ & $0.518(0.00)$ \\
\hline Industry capital intensity & & $-0.0001(0.00)$ & $-0.0002(0.00)$ \\
\hline \multicolumn{4}{|l|}{ Control Variables } \\
\hline TFP $(\log )$ & $0.008(0.00)$ & $0.014(0.00)$ & $0.010(0.00)$ \\
\hline Firm size $(\log )$ & $0.085(0.00)$ & $0.081(0.00)$ & $0.083(0.00)$ \\
\hline Firm age (log) & $-0.022(0.00)$ & $-0.035(0.00)$ & $-0.021(0.00)$ \\
\hline Log likelihood & & $-36378(0.00)$ & $-35208(0.00)$ \\
\hline Wald $\chi^{2}$ & $\begin{array}{r}36246(0.00) \\
19266.56\end{array}$ & 18396.24 & 22033.64 \\
\hline Number of observations & 147,764 & 147,764 & 147,764 \\
\hline
\end{tabular}

Note. All the independent variables are lagged one year. Province, two-digit industry, and year fixed effects are included and not shown. The p-values are reported in parentheses.

WFOEs=wholly foreign owned enterprises; HMT=Hong Kong, Macao, and Taiwan; JVs=Joint Ventures; LOEs=wholly locally owned enterprise

\footnotetext{
${ }^{1}$ This paragraph relies entirely on Lai (2002, p.30)
} 
of operations have lower export intensities than those of the young.

\subsection{The Determinants of Export Strategies}

This section deals with the determinants of the choice of the export strategies, which are classified into three categories according to their export sequences during the observed period. As discussed above, firms can have three different kinds of export strategies: never export, occasionally export, and persistently export. Correspondingly, three groups of firms are identified based on their export strategies: non-exporters, sporadic exporters and persistent exporters. Given the categorical and ordinal nature of the dependent variable, an ordered probit (OPROBIT) model fits well.

Table 3.Determinants of Export Strategies

\begin{tabular}{|c|c|c|c|c|}
\hline \multirow[b]{3}{*}{$\begin{array}{c}\text { Independent } \\
\text { Variables }\end{array}$} & \multicolumn{4}{|c|}{ Export Strategies (Ordered Probit Model) } \\
\hline & \multirow[b]{2}{*}{ Estimates } & \multicolumn{3}{|c|}{ Marginal Effects } \\
\hline & & $\begin{array}{c}\text { Nonexporters } \\
(=1)\end{array}$ & $\begin{array}{c}\text { Sporadic } \\
\text { Exporters }(=2)\end{array}$ & $\begin{array}{c}\text { Persistent } \\
\text { Exporters }(=3)\end{array}$ \\
\hline \multicolumn{5}{|l|}{ Ownership Structure } \\
\hline WFOEs with non-HMT control & $0.306(0.00)$ & $-0.121(0.00)$ & $0.034(0.00)$ & $0.087(0.00)$ \\
\hline WFOEs with HMT control & $0.072(0.04)$ & $-0.028(0.04)$ & $0.010(0.03)$ & $0.019(0.04)$ \\
\hline JVs with non-HMT control & $0.168(0.00)$ & $-0.066(0.00)$ & $0.021(0.00)$ & $0.045(0.00)$ \\
\hline JVs with HMT control & $-0.204(0.00)$ & $0.077(0.00)$ & $-0.031(0.00)$ & $-0.046(0.00)$ \\
\hline JVs with nonstate control & $-0.275(0.00)$ & $0.103(0.00)$ & $-0.042(0.00)$ & $-0.061(0.00)$ \\
\hline JVs with state control & $-0.334(0.00)$ & $0.124(0.00)$ & $-0.052(0.00)$ & $-0.071(0.00)$ \\
\hline WLOEs with nonstate control & $-0.993(0.00)$ & $0.375(0.00)$ & $-0.118(0.00)$ & $-0.257(0.00)$ \\
\hline WLOEs with state control & $-1.077(0.00)$ & $0.352(0.00)$ & $-0.167(0.00)$ & $-0.185(0.00)$ \\
\hline \multicolumn{5}{|l|}{ Industry Characteristics } \\
\hline Industry concentration & $0.740(0.00)$ & $-0.288(0.00)$ & $0.102(0.00)$ & $0.186(0.00)$ \\
\hline Industry export orientation & $2.562(0.00)$ & $-0.984(0.00)$ & $0.349(0.00)$ & $0.635(0.00)$ \\
\hline Industry capital intensity & $-0.002(0.00)$ & $0.001(0.00)$ & $-0.000(0.00)$ & $-0.000(0.00)$ \\
\hline \multicolumn{5}{|l|}{ Control Variables } \\
\hline TFP $(\log )$ & $0.043(0.00)$ & $-0.017(0.00)$ & $0.006(0.00)$ & $0.011(0.00)$ \\
\hline Firm size $(\log )$ & $0.351(0.00)$ & $-0.137(0.00)$ & $0.049(0.00)$ & $0.088(0.00)$ \\
\hline Firm age (log) & $0.060(0.00)$ & $-0.023(0.00)$ & $0.008(0.00)$ & $0.015(0.00)$ \\
\hline Log likelihood & $-127,493.8$ & & & \\
\hline Wald $\chi^{2}$ & $91067.4(0.00)$ & & & \\
\hline Pseudo $\mathrm{R}^{2}$ & 0.2944 & & & \\
\hline Number of observations & 184,705 & & & \\
\hline
\end{tabular}

Note. All the independent variables are lagged one year. Province, two-digit industry, and year fixed effects are included and not shown. The $p$-values are reported in parentheses.

WFOEs=wholly foreign owned enterprises; HMT=Hong Kong, Macao, and Taiwan; JVs=Joint Ventures; LOEs=wholly locally owned enterprise
According to the results in Table 3 , the estimated coefficients of WFOEs with nonHMT control, WFOEs with HMT control and JVs with nonHMT control are positive and statistically significant. In particular, the ownership of WFOEs with nonHMT control increases the probability of them being persistent exporters by 8.7 percent. WFOEs with HMT control and JVs with nonHMT control have corresponding probabilities of about $1.9 \%$ and

$4.5 \%$ respectively. This implies that Chinese manufacturing firms with these three kinds of ownership structures are more likely to export persistently.

In contrast, the other five categories of ownership structures (i.e. JVs with MHT control, JVs with non-state control, JVs with state control, WLOEs with non-state control, and WLOEs with state control) have a negative impact on firms' improving their export status. Among these five categories, wholly locally-owned enterprises with non-state control are least likely to be persistent exporters, followed by WLOEs with state control. It is important to note that the sign of the JVs with HMT control dummy is negative, which is contrary to the results in export propensity and export intensity specifications. This means that joint ventures with HMT control are more likely to export and export more, but will not export persistently compared with other firms with foreign control. The results also show that wholly foreign owned enterprises with non-HMT control have the highest probability of exporting continuously. The joint ventures with non-HMT control are more likely to be persistent exporters than wholly foreign owned enterprises with HMT control. In addition, joint ventures with state control are more likely to be non-exporters than those with non-state control. However, wholly locally owned enterprises with state control are less likely to be non-exporters than those with non-state control.

In relation to industry characteristics, industry concentration has a positive and statistically significant impact on the firms' choice of export strategies. Thus, firms operating in a highly concentrated industry are more likely to export permanently. So are firms operating in the export-oriented and labour-intensive industries. Also, more productive firms are more likely to export continuously while less productive firms are more 
Fu et al., The effects of ownership structure and industry characteristics on China's export performance

likely to export occasionally or not export at all. Firm size and age have the same influence on the firms' export strategies as productivity. Thus, large and old firms are more likely to be persistent exporters.

\section{CONCLUSION}

The main contribution of this paper was to examine the effects of ownership structure and industry characteristics on the export performance in the context of Chinese manufacturing firms. To achieve this aim, three different yet related models were employed, namely, Logit model, Tobit model and Ordered probit model, to investigate the determinants of export propensity, export intensity and export strategies, respectively. Unlike previous studies which simply compare the export behaviour of foreign firms and domestic firms, this study distinguishes between wholly foreign owned enterprises, joint ventures and wholly locally owned enterprises, and between HMT (Hong Kong, Macao, Taiwan) and non-HMT (mainly OECD countries) control, and between non-state and state control within firms. Three industry characteristics at the four-digit level - industry concentration, industry export orientation, and industry capital intensity - are also incorporated in different specifications. This methodology provided some new findings. First, three different specifications gave a consistent conclusion that the presence of wholly-owned firms and joint ventures with foreign control (non-HMT control or HMT control) have had a positive effect on export propensity and intensity. Firms with non-HMT control are more export-oriented than those with HMT control. Furthermore, firms with such characteristics are more likely to be persistent exporters, with the exception of joint ventures with HMT control, which less likely to export persistently. Joint ventures with domestic control (non-state or state control) and wholly locally owned enterprises are less likely to export or improve their export status, and have lower export intensity. Second, the impact of industry concentration on export performance remains inconclusive, meaning further studies or the use alternative measurements are required. The results for the effects of industry export orientation and capital intensity are consistent across the three different models. The results imply that firms operating in export-oriented and labour intensive industries are more likely to export, have high export intensities, and be persistent exporters.

ACKNOWLEDGEMENT We acknowledge generous financial support from the China Scholarship Council (CSC), the Business School of the University of Western Australia (UWA) and the Australian Research Council (ARC). We also thank the participants of an economics brownbag seminar in the University of Western Australia and two anonymous referees for helpful comments and suggestions.

\section{REFERENCES}

Feenstra, R. C. and Hanson, G. H. (2005).Ownership and Control of Outsourcing to China: Estimating the Property-Rights Theory of the Firm. Quarterly Journal of Economics, 120, 729-761.

Filatotchev, I., Stephan, J. and Jindra, B. (2008).Ownership Structure, Strategic Controls and Export Intensity of Foreign-Invested Firms in Transition Economies. Journal of International Business Studies, 39, 1133-1148.

Fung, H.-G., Gao, G. Y., Lu, J. and Mano, H. (2008).Impact of Competitive Position on Export Propensity and Intensity: An Empirical Study of Manufacturing Firms in China. The Chinese Economy, 41, 51-67.

Gao, G. Y., Murray, J. Y., Kotabe, M. and Lu, J. (2010). A "Strategy Tripod" Perspective on Export Behaviour: Evidence from Domestic and Foreign Firms Based in An Emerging Economy. Journal of International Business Studies, 41, 377-396.

Ge, Y. and Chen, Y. (2008). Foreign Ownership and Productivity of Joint Ventures. Economic Development and Cultural Change, 56, 895-920.

Lai, P. (2002). Foreign Direct Investment in China: Recent Trends and Patterns. China and World Economy, 2, 25-32.

Levinsohn, J. and Petrin, A. (2003).Estimating Production Functions Using Inputs to Control for Unobservables. Review of Economic Studies, 70, 317-341.

Zhao, H. and Zou, S. (2002). The Impact of Industry Concentration and Firm Location on Export Propensity and Intensity: An Empirical Analysis of Chinese Manufacturing Firms. Journal of International Marketing, 10, 52-71. 